\title{
INFLUENCE OF ULTRASONIC AND ELECTRICAL PRETREATMENTS ON THE DRYING AND QUALITY CHARACTERISTICS OF KIWI FRUIT SLICES
}

\author{
Hamza Bozkı1 ${ }^{1 *}$, Ahsen Rayman Ergün ${ }^{2}$ \\ ${ }^{1}$ Sakarya University of Applied Sciences, Food Processing Department, Vocational School of Pamukova, Sakarya, \\ Turkey \\ ${ }^{2}$ Food Engineering Department, Faculty of Engineering, Ege University, Izmir, Turkey \\ Received /Geliş: 02.02.2021; Accepted / Kabul: 05.05.2021; Published online / Online bask1: 21.05.2021 \\ Bozker, H., Rayman-Ergün, A. (2021). Influence of ultrasonic and electrical pretreatments on the drying and quality \\ characteristics of kiwi fruit slices. GIDA (2021) 46 (4) 817-829 doi: 10.15237/gida.GD21025
}

Bozkır, H., Rayman-Ergün, A. (2021). Ultrasonik ve elektriksel ön işlemlerin kivi dilimlerinin kuruma ve kalite özelliklerine etkisi. GIDA (2021) 46 (4) 817-829 doi: 10.15237/gida.GD21025

\begin{abstract}
In this study, the drying characteristics and quality properties of electrical (ET) and ultrasound (US) pretreated kiwi fruit slices were investigated. Electrical and ultrasound pretreatments were carried out on the parameters of $100 \mathrm{~V}-40 \mathrm{sec}$. and $35 \mathrm{kHz}-30$ min respectively. After the pretreatments, the kiwi fruit slices were dehydrated using a convective dryer at $50^{\circ} \mathrm{C}$ and $1.5 \mathrm{~m} / \mathrm{s}$ air flow rate. The effects of these pretreatments on the drying rate and quality properties (the total phenolic content, vitamin $\mathrm{C}$, pectin contents, rehydration rate, acidity, and color values) were evaluated. Consequently, the US and ET pretreatments provided an increase in the drying rate by $18.34 \%$ and $21.65 \%$ respectively. The combination of pretreatments (ET+US) increased the drying rate by $35.70 \%$. The ET pretreatment produced minimum changes in the samples' pectin content and color values, and the US application increased the vitamin C, rehydration capacity, and acidity.
\end{abstract}

Keywords: Kiwi fruit, electrical, ultrasound, drying, and quality.

\section{ULTRASONIKK VE ELEKTRIKSEL ÖN İŞLEMLERIN KIVİ DİLIMLERINIIN KURUMA VE KALİTE ÖZELLİKLERİNE ETKİSI}

\section{ÖZ}

$\mathrm{Bu}$ çalışmada, elektriksel (ET) ve ultrases (US) ön işlemi görmüş kivi dilimlerinin kuruma karakteristiği ve kalite özellikleri araştırılmıştır. Elektriksel ve ultrasonik ön işlemler sırasıyla, 100V$40 \mathrm{~s}$ ve $35 \mathrm{kHz}$ frekansta 30 dak. parametreleriyle gerçekleştirilmiştir. Ön işlemlerden sonra kivi dilimleri, $50{ }^{\circ} \mathrm{C}$ 'de ve $1.5 \mathrm{~m} / \mathrm{s}$ hava akış hızında bir konvektif kurutucu kullanılarak kurutulmuştur. $\mathrm{Bu}$ ön işlemlerin kuruma hızı ve kalite özelliklerine (toplam fenolik madde, C vitamini, pektin içerikleri, rehidrasyon hızı, asitlik ve renk değerleri) etkileri değerlendirilmiştir. Sonuç olarak, US ve ET ön işlemleri, kurutma hızında sırasıyla \%18.34 ve \%21.65 artış sağlamıştır. Ön işlemlerin kombinasyonu (ET + US) kuruma hızını \%35.70 artırmıştır. ET ön işlemi, örneklerin pektin içeriği ve renk değerlerinde minimum değişiklik meydana getirirken, US uygulaması kivi dilimlerinde C vitamini, rehidrasyon kapasitesi ve asitlik gibi kalite özelliklerini artırmıştır.

Anahtar kelimeler: Kivi, elektriksel, ultrases, kurutma, kalite

${ }^{*}$ Corresponding author / Yazışmalardan sorumlu yazar

\bozkirhamza@gmail.com,

(c) (+90) 2646160813

且 $(+90) 2646160014$

Hamza Bozkır; ORCID no: 0000-0002-8868-697X

Ahsen Rayman Ergün; ORCID no: 0000-0003-0943-1950 


\section{INTRODUCTION}

Drying is one of the oldest method of food preservation and the most common technique used in the food industry. Conventional air-drying allows longer shelf life and smaller space for storage (Nowacka et al., 2012; Demiray et al., 2017; Bozkir et al., 2021). However, there is a large loss of thermal energy and a lengthy drying time throughout the falling rate period in convective drying (Wang and $\mathrm{Xi}, 2005$ ). Moreover, conventional hot air drying also causes changes in the physical, chemical, and nutritional properties of food such as undesired food flavor, color decomposition, tough texture, severe browning, low rehydration rate, vitamin degradation, and loss of essential amino acids (Deng and Zhao, 2008; Ricce et al., 2016).

In recent years, some pre-treatment operations have been performed to enhance the drying rate, to decrease the initial water content, or to change the fruit tissue structure (Fernandes and Rodrigues, 2007). These pre-treatments include blanching, vacuum, electric pulses, electrical applications, and power ultrasound Jambrak et al., 2007; Fernandes et al., 2008a; Deng and Zhao, 2008; Barba et al., 2015; Çakmak et al., 2016).

Electrical pre-treatment application improves the cell membrane permeability of fruit tissues and increases the coefficients of mass transfer (Bazhal, et al., 2003). Electrical pre-treatment enables water to transition faster from the cell to the fruit surface decreasing the time of drying. The electrical application as a pre-treatment was applied previously for the drying of carrots and mushrooms (Baysal et al., 2012; İçier et al., 2013; Çakmak et al., 2016). Ultrasonic pretreatment is used for decreasing the moisture content or altering the fruit and vegetable tissue microstructure so that drying becomes faster (Azoubel et al., 2010). It was reported that ultrasound pretreatment improves the processes or products chemically, mechanically, and physically (Fernandes et al., 2011). The ultrasonic pretreatment could be applied by immersing of the fruit in water or in a hypertonic aqueous solution (Azoubel et al., 2010). Ultrasound as a pre-treatment was applied for dehydration of pineapple (Fernandes et al., 2008a), genipap, banana, jambo, melon, pineapple, papaya (Fernandes and Rodrigues, 2008), banana (Azoubel et al., 2010), strawberry (GamboaSantos et al., 2014), garlic (Bozkir et al., 2019), and carrot (Santacatalina et al., 2012). However, ultrasound pre-treatment has been investigated for fruit and vegetable drying, to the best of the authors' knowledge, no studies have been available about applying electrical and ultrasound pretreatments prior to the drying of kiwi fruit.

Literature studies with kiwi fruit (Actinidia chinensis) stated that the stableness of kiwi fruit, which has a short-life, is lost during storage because of softening and vitamin loss (Femenia et al., 2009). In addition, drying of this fruit leads to a reduction in precious bioactive ingredients (vitamins, antioxidants, phenolic compounds, and flavor compounds) and sensory properties (color and flavor) (Simal et al., 2005; Kaya et al., 2008; Darıc1 and Şen, 2011). Consequently, in this study, the aims were to evaluate the influences of electrical and ultrasound applications on the conventional air drying of kiwi fruits in terms of drying rates and quality properties.

\section{MATERIALS AND METHODS \\ Material}

Hayward (Actinidia deliciosa) type kiwi fruits were supplied from the markets in Izmir, Turkey. The kiwi fruits were kept at $+4^{\circ} \mathrm{C}$ and $80-90 \%$ relative humidity until processing.

\section{Method \\ Drying procedure \\ Electrical pretreatment}

The electrical pretreatment (ET) was performed using a drum type electroplasmolyzator sketched out with the cooperation of Çermak Machine (Manisa-Turkey). ET possess two drums with stainless steel pins and voltage part, which delivers alternative electric current to the system. The distance between pins was $2.4 \mathrm{~cm}$, distance between the drums was $5 \mathrm{~cm}$, and the cycling speed of cylinders was $25 \mathrm{~s}$ per 1 cycle (Baysal et al., 2007). The ET was carried out at the conditions of $20 \mathrm{~V}-90 \mathrm{~s}, 40 \mathrm{~V}-60 \mathrm{~s}$, and $100 \mathrm{~V}-40$ s. After performing the experiments $100 \mathrm{~V}-40 \mathrm{~s}$ 
was chosen due to ensuring the shortest drying time. The ET pretreatment was performed to whole the kiwi fruits $\left(30^{\circ} \mathrm{C}\right)$, and then the kiwi fruits were washed, peeled and sliced to a thickness of $6 \mathrm{~mm}$ (Çakmak et al., 2016). The production scheme for dried fruit is shown in Fig. 1.

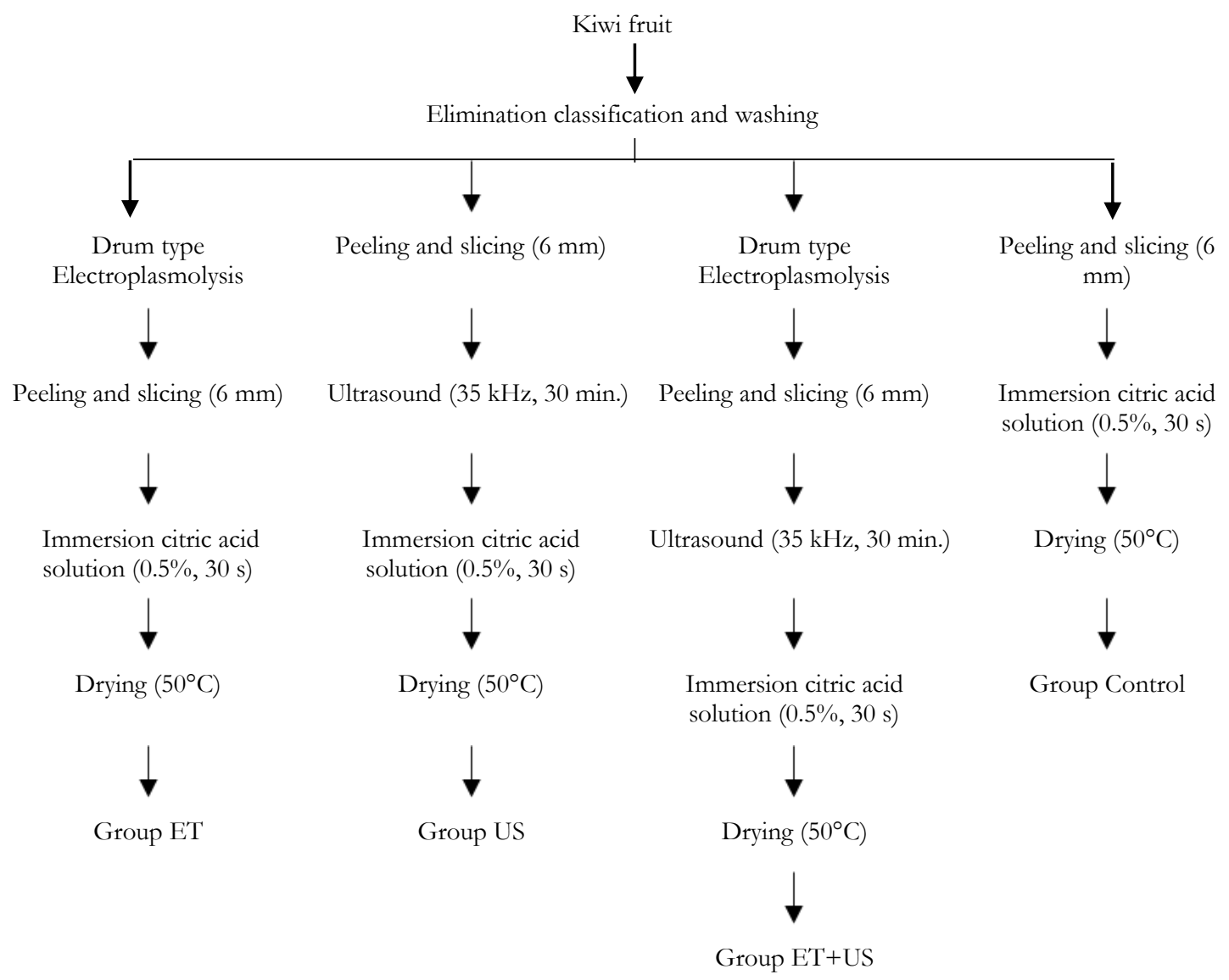

Figure 1. Dried kiwi fruit slices production scheme

*ET: Electrical pre-treatment, US:Ultrasound pre-treatment, and ET+US:Electrical and ultrasound pre-treatment

\section{Ultrasound pretreatment}

The kiwi fruits were washed and peeled. The kiwi fruit samples were sliced to a $6 \mathrm{~mm}$ thickness. Then, the kiwi fruit to water was set to 1:4 (w/w) (Sonorex Super Ultrasonic Bath-RK-106, 100\% power: $480 \mathrm{~W}, 35 \mathrm{kHz}$ and $30^{\circ} \mathrm{C}$ ). The ultrasound pretreatment was performed for 10, 20, and 30 min at $30^{\circ} \mathrm{C}$ (Çakmak et al., 2016). The ultrasound $30 \mathrm{~min}$ application was decided, and it provided the shortest drying time.

\section{Convective drying}

Before convective drying, a sliced $6 \mathrm{~mm}$ sample was immersed into a citric acid solution $(0.5 \%)$ for
$30 \mathrm{~s}$ to reduce the degradation of color. The kiwi fruit slices placed uniformly on a perforated aluminum tray $(18 \times 27 \mathrm{~cm})$ were dried in the tray dryer (Model UOP8, Armfield Limited, England). The operating conditions of the dryer were adjusted as $50^{\circ} \mathrm{C}$ and $1.5 \mathrm{~m} \mathrm{~s}^{-1}$ air velocity. In the drying process, the weights of kiwi fruit slices were weighed with digital scales (RADWAG WTC 2000, Radom, Poland) at each 5 min until moisture content of below 10\%. The initial moisture content of samples were identified as $81 \pm 0.01 \mathrm{~g} / 100 \mathrm{~g}$ (wet basis) using an MOC-63U Shimadzu infrared moisture detector (AOAC, 1990). 


\section{Drying rate}

To collect data the drying process, the weight of the dry matter (d.m.) of kiwi fruits was detected $\left(\mathrm{W}_{\mathrm{s}}\right)$, and the weight of the wet solid (W) was defined at different times $(\mathrm{t})$ :

$X_{t}=\frac{W-W_{s}}{W_{s}}\left(\mathrm{~kg} \mathrm{H} \mathrm{H}_{2} \mathrm{O} / \mathrm{kg} \mathrm{d}\right.$.m. $)$

$\mathrm{X}$ : free moisture content $\left(\mathrm{kg} \mathrm{H}_{2} \mathrm{O} / \mathrm{kg} \mathrm{d}\right.$.m.) was computed for every value of $\mathrm{Xt}$ for the constant drying and $\mathrm{Xe}$ : equilibrium moisture content $(\mathrm{kg}$ $\mathrm{H}_{2} \mathrm{O} / \mathrm{kg}$ d.m.) was determined.

$X=X_{t}-X_{e}$

The drying rate of kiwi fruit slices (R) was calculated using equation (3),

$$
R=-\left(\frac{W_{S}}{A}\right) *\left(\frac{d x}{d t}\right)
$$

where $A$ is the surface field of drying process $\left(\mathrm{m}^{2}\right)$ (Çakmak et al., 2016).

The moisture ratio of kiwi fruit slices (MR) was computed using equation 4.

$M R=\frac{M_{t}-M_{e}}{M_{i}-M_{e}}$

where $\mathrm{Mt}$ is the moisture content at any time, Mi is the initial moisture content, and $\mathrm{Me}$ is the equilibrium moisture content $\left(\mathrm{kg} \mathrm{H}_{2} \mathrm{O} / \mathrm{kg}\right.$ d.m.). The effective moisture diffusivity ( $\mathrm{D}_{\text {eff }}$ ) of the samples was computed using Fick's laws diffusion (Eq. 5).

$M R=\frac{8}{\pi^{2}} \sum_{n=1}^{\infty} \frac{1}{(2 n-1)^{2}} \exp \left[-(2 n-1)^{2} \pi^{2} \frac{D_{e f f}}{4 L^{2}} t\right]$

where $D_{\text {eff }}$ is the effective moisture diffusivity $\left(\mathrm{m}^{2} / \mathrm{s}\right)$, $\mathrm{t}$ is the time $(\mathrm{s})$, and $\mathrm{L}$ is the thickness of kiwi fruit slices. The only first term of equation (6) was taken into to account, because of long drying time; it was presented in a logarithmic form.

$\ln (M R)=\ln \left(\frac{8}{\pi^{2}}\right)-\left(\pi^{2} \frac{D_{\text {eff }}}{4 L^{2}} t\right)$

The effective diffusion coefficients of samples (slope) was computed by plotting ln (MR) versus drying time using equation (7) (Demiray et al., 2017; Tekgül and Çalışkan Koç, 2020).

slope $=\pi^{2} \frac{D_{e f f}}{4 L^{2}}$

\section{Methods of Analyses}

The quality characteristics were investigated using physical and chemical analyses. Samples were analyzed to determine the following:

The moisture content was determined using $5 \mathrm{~g}$ sliced kiwi fruit samples and analyzing them with an infrared moisture detector at $105^{\circ} \mathrm{C}, 1 \mathrm{~h}$ (Shimadzu MOC-63U). The total acidity was measured using the potentiometric titration of the acidity by placing $10 \mathrm{~g}$ of a sample into $90 \mathrm{~mL}$ of deionized water. After filtration, the $10 \mathrm{~g}$ filtrate was taken to titration, with a solution of $0.1 \mathrm{~N}$ $\mathrm{NaOH}$ (Merck, Darmstadt, Germany) up to a $\mathrm{pH}$ 8.1. The result is given as $\mathrm{g} / 100 \mathrm{~g}$ dry matter (d.m.) when referencing the citric acid (AOAC, 1995). The $\mathrm{pH}$ values were identified with a $\mathrm{pH}-$ meter (WTW InoLab, Weilheim, Germany) (AOAC, 1995). The water activity of samples was detected using the water activity detector Testo AG 400 (Germany). The total phenolic content of samples was determined using the method of Folin-Ciocalteau (Franke et al., 2004). The amount of total phenolic content in the samples expressed as milligrams of gallic acid (SigmaAldrich Corp., St. Louis) equivalents (GAE) per gram of dry basis. The ascorbic acid content of samples was determined with the spectrophotometric (Varian Cary 50 Scan spectrophotometer) method (Hiş1 2004). For standart curve the oxalic acid (Merck) solution (4\%), a dye solution (2,6-dichloroindophenol) and ascorbic acid (Riedel de Haen, Hannover, Germany) solution using a series of different concentrations were prepared and the absorbance at a wavelength of $518 \mathrm{~nm}$ against a standard showing the concentration of vitamin C curve was obtained $10 \mathrm{~g}$ sample and $90 \mathrm{~mL}$ of stabilizer solution was mixed and then filtered with filter paper (Whatman No.1). Two separate test tubes containing $1 \mathrm{~mL}$ of sample and $9 \mathrm{~mL}$ of distilled water which is blank and $1 \mathrm{~mL}$ of sample and $9 \mathrm{~mL}$ of dye solution were prepared. The concentration was determined from the standard curve versus the absorbance value by multiplying by 10 for calculating the amount of ascorbic acid in the $100 \mathrm{~g}$ sample and expressed as $\mathrm{mg} / 100 \mathrm{~g}$ d.m. 
The rehydration capacity of dried kiwi fruit samples was determined in accordance with Cui et al. (2008) and Çakmak et al. (2016). The rehydration ratio was computed using equation 8 .

$$
\text { Rehydration ratio }=\frac{\text { Weight rehydrated sample }(\mathrm{g})}{\text { Weight dry sample }(\mathrm{g})}
$$

Bulk density of samples was computed using equation (9) and the volume of $2 \mathrm{~g}$ dried sample measured using a graduated cylinder (Goula and Adamopoulos, 2005).

$$
\rho_{\text {bulk }}=\frac{\mathrm{m}}{\mathrm{V}}(\mathrm{g} / \mathrm{ml})
$$

Pectin content was investigated according to Anon (1968). The method is based on the extraction of pectin with ethanol after centrifugation; the precipated part was treated with $\mathrm{NaOH}$ and completed to $100 \mathrm{~mL}$ with deionized water. After filtration, samples were prepared with carbazol and ethanol. Six milliliters of sulfiric acid were added to both samples then they were placed in a water bath for $5 \mathrm{~min}$. Then absorbans values were taken at $525 \mathrm{~nm}$ with Varian Cary 50 Scan (Australia) spectrophotometre and pectin contents were calcuated with the calibration curve, which was made by using gallactronic acid anhydrate standards. Results were expressed as $\mathrm{mg}$ gallactronic acid anhydrate $(\mathrm{GA}-\mathrm{AH}) / 100 \mathrm{~g}$ dry matter. The Color values $\left(\mathrm{L}^{*}, \mathrm{a}^{*}\right.$, and $\left.\mathrm{b}^{*}\right)$ of samples were detected with a Hunter Lab Color CX1633 (Flex, Management Company).

\section{Statistical analysis}

Statistical analysis was analyzed using SPSS 20 (SPSS Inc., USA. The one-way analysis of variance (ANOVA) and Duncan's multiple range test $(P<0.05)$ was performed to determine the difference between the pretreatment groups. The drying experiments were repeated three times, and all measurements were triplicated.

\section{RESULTS AND DISCUSSION}

Effects of pretreatments on the drying characteristics

The dimensionless moisture content (MR) versus drying time was shown in Fig. 2. The MR of the samples reduced exponentially with drying time. The results agreed with the previous studies about varied materials when dried (Gogus and Maskan, 2001; Kadi and Hamlat, 2002).

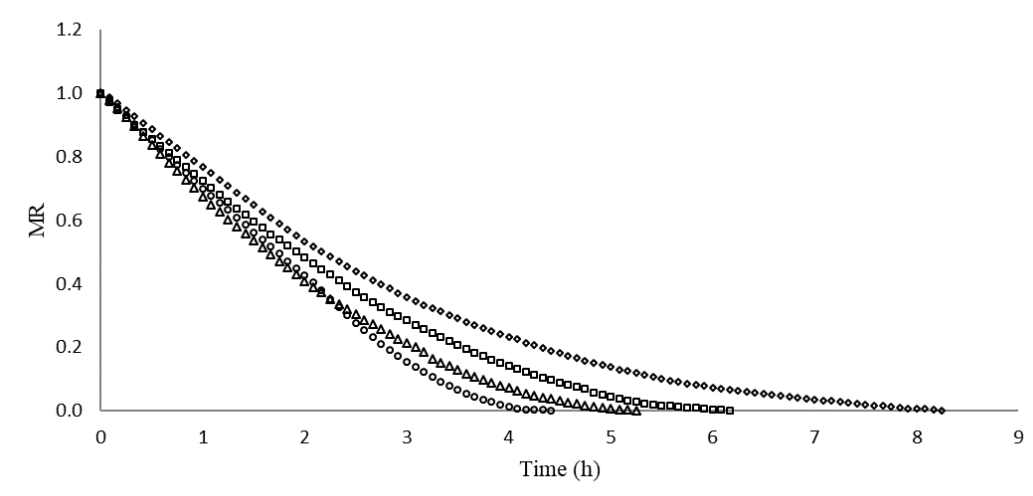

Figure 2. The dimensionless moisture content in the untreated and the pretreated kiwi slices during drying ( $\diamond$ Control, $\square \mathrm{ET}, \Delta \mathrm{US}$, oET+US).

*ET: Electrical pre-treatment, US:Ultrasound pre-treatment, and ET+US:Electrical and ultrasound pre-treatment

In figure 3 the changes in the moisture contents of samples due to time were given. The kiwi fruit slices' moisture contents were about $4.26 \mathrm{~kg}$ $\mathrm{H}_{2} \mathrm{O} / \mathrm{kg}$ d.m. for the control and ET and $4.66 \mathrm{~kg}$
$\mathrm{H}_{2} \mathrm{O} / \mathrm{kg}$ d.m. for US and US+ET groups, respectively. The ultrasound pre-treatment increased the initial moisture content of samples in the US and US+ET groups. Similarly, the 
ultrasound pretreated apple slices at a frequency of $35 \mathrm{kHz}$ for $30 \mathrm{~min}$ increased the moisture content from $5.6 \mathrm{H}_{2} \mathrm{O} / \mathrm{kg}$ d.m. to $7.5 \mathrm{H}_{2} \mathrm{O} / \mathrm{kg}$ d.m. (Fijalkowska et al., 2016). Moreover, it was reported that the ultrasound-pretreated banana prior to drying created an increasing the moisture content (Fernandes and Rodrigues, 2007; Azoubel et al., 2010). The ultrasound pretreatment created a rapid compression and expansion of the food cells. This phenomenon is called the sponge effect (Mulet et al., 2003; Miano et al., 2016; Ricce et al., 2016). The US and ET pre-treatments decreased the drying time compared to the control samples. The time was $8.25 \mathrm{~h}$ in the control group but in the ET pretreated samples 6.17 hours was sufficient for drying. Decrease of the drying time after electrical pre-treatment was explained due to the electroporation and thermal breakdown of the membranes (Wang and Sastry, 2002). In the US group this time falls to 5.25 hours, whereas, in the group of combined pretreatments the samples dried within 4.42 hours. The ultrasound pretreatment reduced the drying time compared to the control. Similar results were reported that ultrasound decreased the drying time of pineapples by over 1 hour of air-drying time (Fernandes et al., 2008a). It was reported that mass transfer was affected with the break down the cell organelles before causing in the cell wall disruption (Rojas et al., 2016).

Similar results were found in accordance with former researches it was detected ultrasound pretreatment reduced the drying time $5-40 \%$ for banana (Fernandes and Rodrigues, 2007; Azoubel et al., 2010), 36\% for pineapple (Fernandes et al., 2008a), 28\% for melon (Fernandes et al., 2008b), $16 \%$ for papaya (Fernandes et al. 2008c), and $17 \%$ for apple (Fijalkowska et al., 2016).

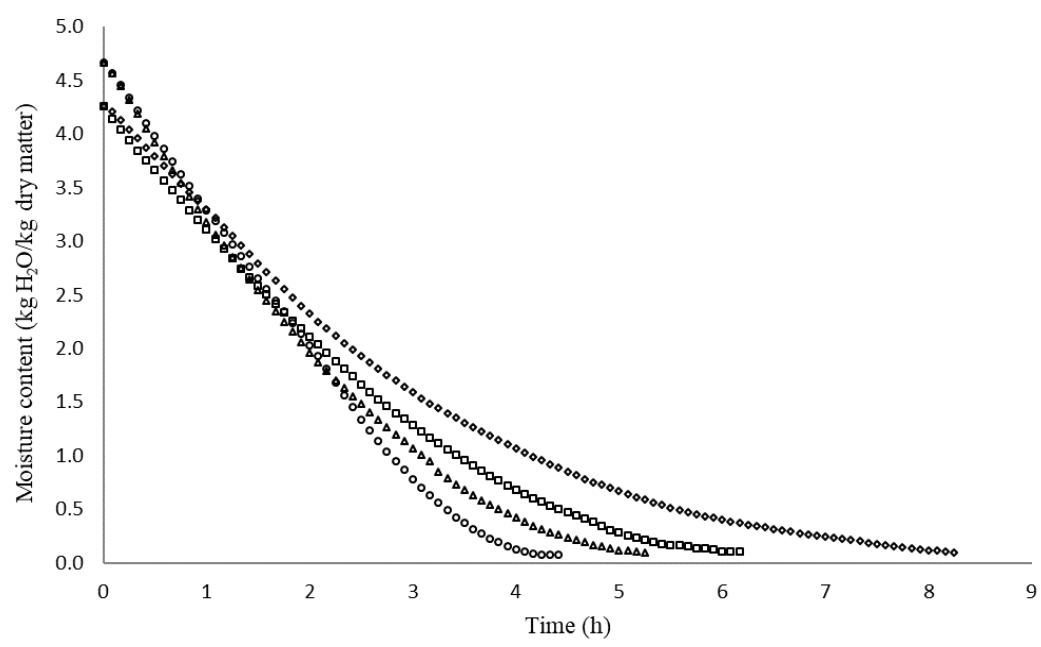

Figure 3. Drying curves for the sliced kiwi fruit ( $\diamond$ Control, $\square \mathrm{ET}, \Delta \mathrm{US}$, oET+US).

*ET: Electrical pre-treatment, US:Ultrasound pre-treatment, and ET+US:Electrical and ultrasound pre-treatment

In figure 4 the drying rates changing with the moisture content were given. The constant rate period did not exist so drying occurred at a falling rate period. The drying rate of samples reduced as the moisture content declined. Similar to this study, the drying kinetics exhibited only a falling rate period in the research of Simal et al. (2005). The drying rates were found as $0.713 \mathrm{~kg}$ $\mathrm{H}_{2} \mathrm{O} / \mathrm{h} \mathrm{m}^{2}$ in the control group; $0.844 \mathrm{~kg}$
$\mathrm{H}_{2} \mathrm{O} / \mathrm{h} . \mathrm{m}^{2}$ in the ET group, $0.867 \mathrm{~kg} \mathrm{H} \mathrm{H}_{2} \mathrm{O} / \mathrm{h} . \mathrm{m}^{2}$ in the US and $0.968 \mathrm{~kg} \mathrm{H} \mathrm{H}_{2} \mathrm{O} / \mathrm{h} \cdot \mathrm{m}^{2}$ in the combined group. The drying rate increased in the ET, US, US+ET groups to 18.34, 21.65, and $35.70 \%$, respectively, compared to the control group. Similar to these results, It was determined that the drying rate of the electrical and ultrasound pretreated mushroom slices increased about $37.10 \%$ compared to untreated group 
(Çakmak et al., 2016). The drying rate of the ultrasound pretreated apple cubes (30 $\mathrm{min})$ resulted in a higher value $(0.052 \mathrm{~kg} / \mathrm{kg}$ d.b. min) than the group with untreated group $(0.042 \mathrm{~kg} / \mathrm{kg}$ d.b. min) (Nowacka et al., 2012). Similarly, the increase of the drying rate for the ultrasound pretreatment samples was observed in carrot slices, apples and, scallop (Ricce et al., 2016; Magalhãesa et al., 2017; Bai et al., 2017). It was found that high-intensity ultrasound increased the drying rate of persimmon at the lowest air velocities $(0.5,1$, 2 , and $4 \mathrm{~m} / \mathrm{s}$ ) (Cárcel et al., 2007). The ultrasound was effective on heat sensitive fruits, such as strawberry, for improving the drying rate (GarciaNoguera et al., 2010; Gamboa-Santos et al., 2014). In addition, for the other types of drying applications, sonication was also preferred because the ultrasonic treatment enhanced the dehydration rate and reduced the time required for the microwave freeze drying of sea cucumbers (Duan et al., 2008) and the ultrasonic application during atmospheric freeze drying of carrot provided a decrease of drying time by $60 \%$ (Santacatalina et al., 2012).

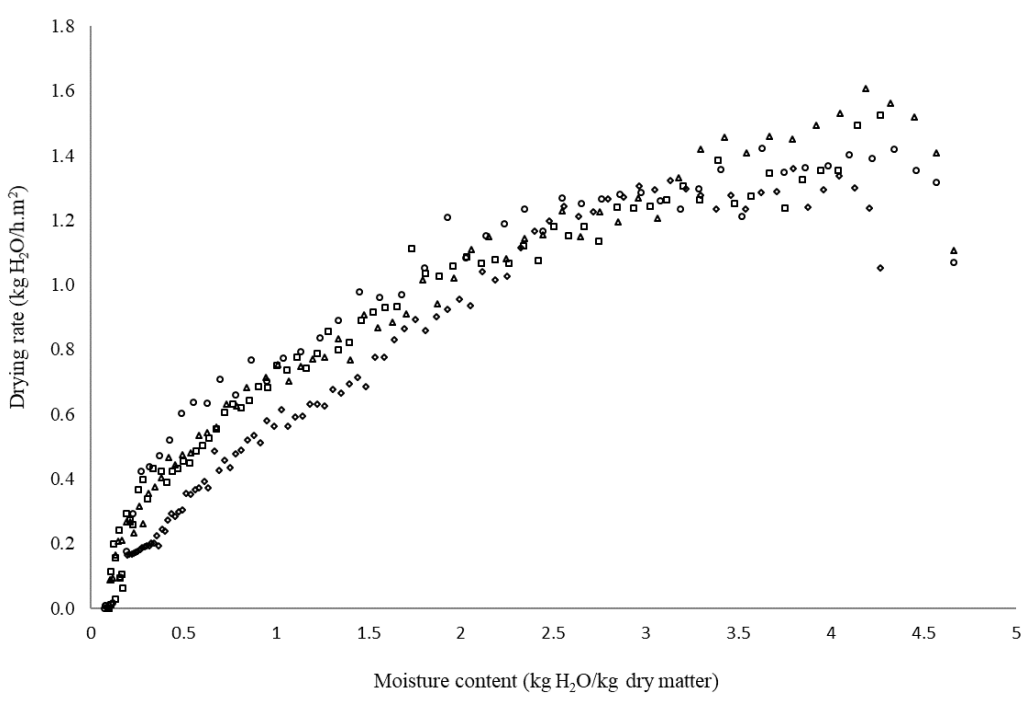

Figure 4. Drying rate versus the moisture content for sliced kiwi fruit ( $\diamond$ Control, $\square \mathrm{ET}, \Delta \mathrm{US}$, oET+US).

*ET: Electrical pre-treatment, US: Ultrasound pre-treatment, and ET+US:Electrical and ultrasound pre-treatment

The moisture transfer during the drying of kiwi fruit slices were computed using Fick's laws diffusion model. The effective moisture diffusivity $\left(\mathrm{D}_{\text {eff }}\right)$ of the samples were found to be as $6.085,7.303,9.128$, and, $10.954 \times 10^{-10} \mathrm{~m}^{2} \mathrm{~s}^{-1}$ for the control, ET, US, and ET+US respectively. It was reported that the effective moisture diffusivity of hot air-dried kiwi fruit slices $(30-$ $90^{\circ} \mathrm{C}$ ) varied between 3.00 and $17.21 \times 10^{-10} \mathrm{~m}^{2} \mathrm{~s}^{-}$ ${ }^{1}$ (Simal et al., 2005). Nowacka et al. (2012) reported that the effective moisture diffusivity of ultrasound pretreated apple cubes (30 min) prior to hot air drying $\left(70^{\circ} \mathrm{C}, 1.5 \mathrm{~m} / \mathrm{s}\right)$ raised $(2.168 \times$ $10^{-9} \mathrm{~m}^{2} \mathrm{~s}^{-1}$ ) when compared to untreated group $\left(1.829 \times 10^{-9} \mathrm{~m}^{2} \mathrm{~s}^{-1}\right)$. Similarly, Fijalkowska et al. (2016) reported that the effective diffusivity coefficient of ultrasound pretreated apple slices prior to hot air-drying $\left(70^{\circ} \mathrm{C}, 2 \mathrm{~m} / \mathrm{s}\right)$ resulted in a higher value than the untreated sample. In another study, the effective moisture diffusivity of the kiwi fruit slices in drying after the application of the ultrasound pretreatment increased parallel with the treatment time when the thickness was 6 $\mathrm{mm}$. They also emphasized that the thickness of $6 \mathrm{~mm}$ was more effective than the thickness of 8 $\mathrm{mm}$. It was stated that increases in the value of diffusivity had a great significance during the drying stage (Toosi et al., 2011). Kek et al. (2013) 
who studied the osmotic dehydration of guava slices via indirect sonication using an ultrasonic bath system and direct sonication using an ultrasonic probe system found that applying ultrasound pre-osmotic treatment in $70^{\circ}$ Brix before the hot air drying, decreased the drying time by $33 \%$, and increased the effective diffusivity by $35 \%$.

\section{Effects of pretreatments on the quality parameters}

The final moisture content was below $10 \mathrm{~g}$ water $/ 100 \mathrm{~g}$ dry matter. There were no significant difference among the moisture contents of the pretreated groups $(p>0.05)$. However, the moisture content of the control groups were significantly different from the ET and the US $(P<0.05)$. The acidity was found highest in the US group and lowest in the combination group. It could be said that ultrasound pretreated was more effective for cell degradation than ET in terms of releasing the compounds, but after the drying process the acidic compounds diminished. The difference between the pretreated and control groups were statistically significant $(P<0.05)$ as shown in the Table 1. After the drying process total acidity of sample reduced so, the $\mathrm{pH}$ values increased. In the control group this value was 3.48 , in US+ET group the value was found as 3.63. Castaldo et al. (1992) found that the $\mathrm{pH}$ values of kiwi puree samples changes between 3.11 - 3.47. Femenia et al. (2009) found the $\mathrm{pH}$ values of kiwi fruit between $4.0 \pm 0.3-5.3 \pm 0.5$ for unripe, half-ripe, and ripe fruits.

The water activities of the samples were also shown in the Table 1. In the US pretreated group, the water activity was found higher than the other groups. This was because of the high moisture content of this group. The difference between the pretreated and untreated samples was found statistically significant $(P<0.05)$. Kek et al. (2013) identified the water activity of hot-air dried guava as 0.48 whereas the sonicated samples had higher values $(0.53-0.61)$.

Table 1. Some quality characteristics of dried kiwi slices

\begin{tabular}{|c|c|c|c|c|c|c|c|c|c|}
\hline $\begin{array}{l}\frac{\mathscr{Q}}{\tilde{D}} \\
\underset{\tilde{D}}{\tilde{D}}\end{array}$ & 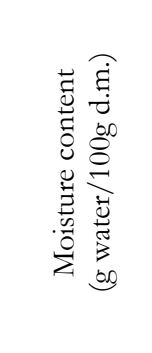 & 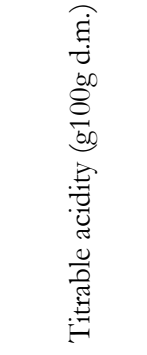 & I & 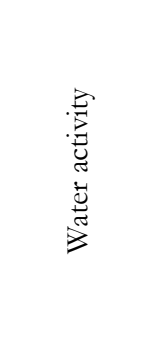 & 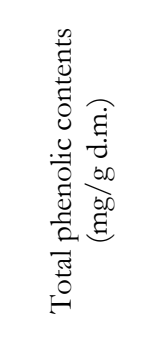 & 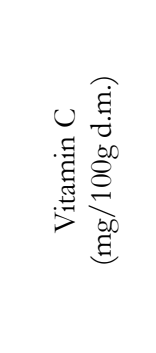 & 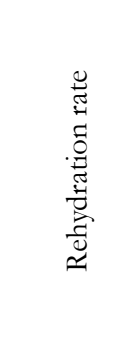 & 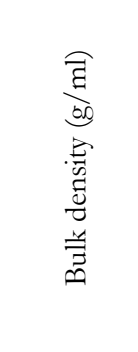 & 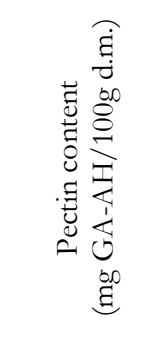 \\
\hline Control & $7.210 \pm 0.11^{\mathrm{b}}$ & $3.527 \pm 0.012^{\mathrm{b}}$ & $3.485 \pm 0.005^{\mathrm{c}}$ & $0.496 \pm 0.001^{\mathrm{d}}$ & $4.888 \pm 0.037^{\mathrm{a}}$ & $41.417 \pm 0.211^{b}$ & $3.098 \pm 0.003^{\mathrm{d}}$ & $0.414 \pm 0.001^{\mathrm{a}}$ & $8.104 \pm 0.134^{\mathrm{d}}$ \\
\hline ET & $7.715 \pm 0.365^{\mathrm{a}}$ & $3.246 \pm 0.013^{c}$ & $3.597 \pm 0.006^{b}$ & $0.528 \pm 0.001^{b}$ & $4.576 \pm 0.055^{\mathrm{c}}$ & $47.647 \pm 1.165^{\mathrm{a}}$ & $3.190 \pm 0.001^{c}$ & $0.281 \pm 0.017 \mathrm{c}$ & $9.535 \pm .355^{c}$ \\
\hline US & $7.775 \pm 0.215^{a}$ & $3.717 \pm 0.101^{\mathrm{a}}$ & $3.445 \pm 0.005^{\mathrm{d}}$ & $0.543 \pm 0.001^{\mathrm{a}}$ & $4.700 \pm 0.063^{b}$ & $48.992 \pm 1.145^{\mathrm{a}}$ & $3.452 \pm 0.001^{b}$ & $0.305 \pm 0.005^{b}$ & $10.851 \pm 0.153^{b}$ \\
\hline $\mathrm{ET}+\mathrm{US}$ & $7.405 \pm 0.195^{\mathrm{ab}}$ & $3.154 \pm 0.026^{\mathrm{d}}$ & $3.635 \pm 0.005^{\mathrm{a}}$ & $0.502 \pm 0.003^{c}$ & $4.468 \pm 0.060^{\mathrm{d}}$ & $30.154 \pm 0.829^{c}$ & $3.490 \pm 0.002^{\mathrm{a}}$ & $0.243 \pm 0.013^{\mathrm{d}}$ & $13.699 \pm 0.170^{\mathrm{a}}$ \\
\hline
\end{tabular}

Different letters ( ${ }^{a}$ to ${ }^{\mathrm{d}}$ ) within columns represent significant difference at the level of $P<0.05$.

*ET: Electrical pre-treatment, US:Ultrasound pre-treatment, and ET+US:Electrical and ultrasound pre-treatment

The effect of the applications on the total phenolic contents of the ET, US and, ET+US groups were detected statistically significant $(P<0.05)$. The US pretreated samples had the higher total phenolic content than ET and ET+US groups. Park et al. (2014) found the total polyphenols of Hayward type kiwi fruit as $4.48 \pm$
0.44 (mg GAE/g). For the kiwi fruit, the phenolics were found as $5.62 \pm 0.65 \mathrm{mg} \mathrm{GAE} / \mathrm{g}$ d.m., and the flavonoids were found as $1.68 \pm 0.1$ $\mathrm{mg}$ catechin equivalent/g d.m. (Gorinstein et al., 2009). Due to these phenolic compounds in different cultivars the antioxidant contents of the kiwi fruits were found between $1.61 \pm 0.15$ to 42.1 
$4 \pm 4.32 \mathrm{mg} \mathrm{GAE} / \mathrm{g}$ d.m. (Park et al., 2014). It was noticed that the total phenolic content of the dried kiwi fruit slices using hot air $\left(40-60^{\circ} \mathrm{C}\right)$ between 500 and $958.70 \mathrm{mg}$ gallic acid/100g d.m. (Chin et al., 2015). Similarly, to these results Opalic et al. (2009) reported that the ultrasound pre-treatment of dried apple causes a decrease in the total phenol content. The loss in the phenolics and anthocyanins was explained with the cell rupture surface after cavitation in the ultrasound treatments (Stojanovic and Silva, 2007). In contrast to this study, the total phenolics content of hot air dried apple slices decreased with temperature, but at high air velocity, the retardation of thermal degradation occurred (Vega-Gálvez et al., 2012).

In Table 1, the vitamin $C$ contents of kiwi fruit slices were given as $\mathrm{mg} / 100 \mathrm{~g}$ d.m. The vitamin C content of US pretreatment group was raised by $18 \%$ in comparison with untreated group. However, in the combined ET+US group the vitamin $\mathrm{C}$ loss was found as $17.5 \%$. The difference was statistically significant in all groups compared to the untreated groups $(P<0.05)$. However, the difference between the US and ET groups were not statistically significant $(p>0.05)$. Indeed, ascorbic acid which is known as being sensitive to heat, light, and processes, the loss was an expected result, but, the pretreatments minimized the losses. In contrast to this study, decreases in the L-ascorbic acid after sonication were determined in a previous study (Lee et al., 2005). Kaya et al. (2010) determined that the vitamin $\mathrm{C}$ of dried kiwi slices using hot air $(35,45$, 55 , and $65^{\circ} \mathrm{C}$ and velocities at $0.3,0.6$ and $0.9 \mathrm{~m}$ $\mathrm{s}^{-1}$ ) ranged between 27.47 and 117.65 vitamin $\mathrm{C}$ $\mathrm{mg} / 100 \mathrm{~g}$ of kiwi fruit. Çalışkan et al. (2015) reported that the vitamin $C$ of freeze dried kiwi fruit was found as $40.95-54.97 \mathrm{mg} / 100 \mathrm{~g}$.

The rehydration capacity was effective on the continuity, and sensory quality (Erbay et al., 2009). In Table 1 , the rehydration capacities were given for the samples. The ET+US group was found as the group that had the higher capacity. This showed that, electrical and ultrasound assisted drying produced only minimal damage to the product. The rehydration capacity was found higher in the US assisted atmospheric freeze drying than atmospheric freeze drying of carrot (Santacatalina et al., 2012). The rehydration ratio changed with air velocity and temperature indicating tissue damage due to applications in the apple slices (Vega-Gálvez et al., 2012). The maximum bulk density was determined in the control group and the minimum in the combination group. It was determined that there was a significant difference among the bulk densities of all the samples $(P<0.05)$.

In all the pretreated samples when compared to the control group due to the cell degradation the total pectin contents increased and it was found statistically significant $(P<0.05)$. Femenia et al. (2009) investigated the pectin contents of air dried kiwi fruits at different ripening stages. They mentioned that the degree of methylesterification of pectin changes with ripening and methylated pectin was more resistant to degradation and solubilization because of the heat effect.

$L^{*}, a^{*}$, and $b^{*}$ values samples were measured and shown in the Table 2. It was found that the maximum and minimum lightness values were the ET and ET+US groups respectively. The difference was not statistically significant in the US when compared to the untreated group $(p>0.05)$. Similar results were found in previous studies such as the ultrasound pretreatment applied green peas and potatoes had no effect on the color of plant tissue compared to the control samples (Bantle and Eikevik, 2011; Schössler et al., 2012). It was found that the difference between $a^{*}$ value of all groups was determined statistically significant $(P<0.05)$. Similarly, Fijalkowska et al. (2016) reported that the $\mathrm{a}^{*}$ value of the ultrasound pretreated apple slices before hot air-drying increased more than that of the untreated sample group. It has been determined that the $b^{*}$ values decreased after pre-treatments. The changes in the $\mathrm{b}^{*}$ values were found significant $(P<0.05)$. Kek et al. (2013) who studied the hot air drying of guava slices found that the ultrasound pre-osmotic treatment decreased the total color change by 38\%. They also indicated that ultrasound before air drying 
caused a decrease in the $a^{*}$, and increase in the $b^{*}$ values. Vega-Gálvez et al. (2012) indicated that the color difference showed the best results at $80^{\circ} \mathrm{C}$ for the drying of apples. In parallel with our results, the values of the browning index showed that hot air drying caused more brown compounds in the kiwi fruit (Mohammadi et al., 2008). After air the drying of kiwi fruit, the $\mathrm{L}^{*}$ and $\mathrm{b}^{*}$ reduced, and the $\mathrm{a}^{*}$ value increased during drying (Maskan, 2001). It was previously explained by Pingret et al. (2013) that ultrasound causes color changes due to the degradation of pigments and browning reactions in the fruits and fruit products.

Table 2. Color properties of dried kiwifruit samples

\begin{tabular}{lccc}
\hline Samples & $\mathrm{L}^{*}$ & $\mathrm{a}^{*}$ & $\mathrm{~b}^{*}$ \\
\hline CONTROL & $44.94 \pm 0.04^{\mathrm{b}}$ & $-9.24 \pm 0.02^{\mathrm{a}}$ & $31.835 \pm 0.09^{\mathrm{a}}$ \\
ET & $47.51 \pm 0.08^{\mathrm{a}}$ & $-6.95 \pm 0.02^{\mathrm{d}}$ & $24.96 \pm 0.03^{\mathrm{c}}$ \\
US & $46.24 \pm 0.12^{\mathrm{ab}}$ & $-7.87 \pm 0.03^{\mathrm{c}}$ & $28.44 \pm 0.01^{\mathrm{b}}$ \\
ET+US & $38.12 \pm 1.53^{\mathrm{c}}$ & $-8.83 \pm 0.05^{\mathrm{b}}$ & $23.34 \pm 0.07^{\mathrm{d}}$ \\
\hline
\end{tabular}

Different letters ( ${ }^{a}$ to ${ }^{d}$ ) within columns represent significant difference at the level of $P<0.05$.

*ET: Electrical pre-treatment, US:Ultrasound pre-treatment, and ET+US:Electrical and ultrasound pre-treatment

\section{CONCLUSION}

The drying rate increased by $18.34,21.65$, and $35.70 \%$ with the applications of ET, US, and a combination of them, respectively, when compared to the control samples. While the mass transfer and diffusivity increased, the drying time of the kiwi slices decreased due to cell degradation. It was found that the ultrasound pretreatments protected the quality characteristics of the samples such as total phenolic content, rehydration capacity, and acidity better than the other applications. Losses in the $a^{*}$ values of the kiwi samples were due to the oxidation and browning reactions and were found to be minimized in the ET pretreated samples. The bulk density values were found lower in the pretreated groups compared to the control samples due to the shrinkage after quick drying. The results show that ET, US, and also the combination of them improves the drying quality and also the chemical and physical properties of kiwi fruit slices. In further studies, this subject could be evaluated for the sensory quality of the fruits and vegetables.

\section{CONFLICT OF INTEREST}

The authors declare no conflict of interest.

\section{AUTHOR CONTRIBUTION}

Hamza Bozkir: Conceptualization, data curation, investigation, methodology, supervision, writing review \& editing, formal analysis. Ahsen Rayman
Ergün: Conceptualization, data curation, investigation, methodology, writing - review \& editing, formal analysis.

\section{REFERENCES}

ANON, (1968). IFJU, Methods of analyses. Method-26. International federation of fruit juice producers. 10, Rue De Liege, Paris, France.

AOAC, (1990). Official methods of analysis of the association of official analytical chemists (15th ed.) Washington, DC, Association of Official Analytical Chemists

AOAC, (1995) Official methods of analysis of AOAC international (16th ed.). Arlington, VA: Association of Official Analytical Chemist

Azoubel, P.M., Baima, M.D.A.M., Amorim, M.D.R., Oliveira, S.S.B. (2010). Effect of ultrasound on banana CV pacovan drying kinetics. J Food Eng, 97(2), 194-198.

Bantle M, Eikevik TM, (2011) Parametric study of high-intensity ultrasound in the atmospheric freeze drying of peas. Drying Technol, 29, 12301239.

Barba, F.J., Parniakov, O., Pereira, S.A., Wiktor, A., Grimi, N., Boussetta, N., Vorobiev, E. (2015). Current applications and new opportunities for the use of pulsed electric fields in food science and industry. Food Res Int, 77(4), 773-798. 
Baysal, T., Icier, F., Yıldız, H., Demirdöven, A. (2007). Effects of electroplasmolysis applications on yield and quality in pomegranate and cherry juice production. Ege University, Scientific Research Project-07 BIL 027, Turkey

Baysal, T., Rayman, A., Bozkır, H. (2012). Investigation of the effects of electroplasmolysis application on drying. Proceedings of the International conference on Bio and Food Electrotechnologies (BFE), Salerno, ITALY, 58.

Bazhal, M.I., Ngadi, M.O., Raghavan, V.G.S. (2003). Influence of pulsed electroplasmolysis on the porous structure of apple tissue. Biosyst Eng, 86, 51-57.

Bozkir H, Tekgül Y, Erten ES. (2021). Effects of tray drying, vacuum infrared drying, and vacuum microwave drying techniques on quality characteristics and aroma profile of orange peels. J Food Process Eng, 2021;44:e13611.

Bozkir, H., Rayman Ergün, A., Tekgül, Y. (2019). Ultrasound as pretreatment for drying garlic slices in microwave and convective dryer. Food $S_{c i}$ Biotechnol, 28, 347-354.

Çakmak, R.Ş, Tekeoğlu, O., Bozkır, H., Ergün, A.R., Baysal, T. (2016). Effects of electrical and sonication pretreatments on the drying rate and quality of mushrooms. LWT-Food Sci Technol, 69, 197-202.

Çalıskan, G., Ergun, K., Dirim, S.N. (2015). Freeze drying of kiwi (Actinidia deliciosa) puree and the powder properties. Ital J Food Sci, 27(3), 385-396.

Cárcel, J.A., García-Pérez, J.V., Riera, E., Mulet, A. (2007). Influence of high-intensity ultrasound on drying kinetics of persimmon. Drying Technol, 25:1, 185-193.

Castaldo, D., Lo, Voi, A., Trifiro, A., Gherardi, S. (1992). Composition of Italian kiwi (Actinidia chinensis) puree. J Agric Food Chem, 40, 594-598.

Chin, S.K., Siew, E.S, Soon, W.L. (2015). Drying characteristics and quality evaluation of kiwi slices under hot air natural convective drying method. Int Food Res J, 22(6), 2188-2195.
Cui, Z.W., Li, C.Y., Song, C.F., Song, Y. (2008). Combined microwave vacuum and freeze drying of carrot and apple chips. Drying Technol, 26:12, 1517-523.

Darıc1, S., Şen, S. (2011). Investigating the effect of air flow rate on the drying rate of kiwi fruit. $X$. Congress of National Installation, Izmir- Turkey.

Demiray, E., Seker, A., Tülek, Y. (2017). Drying kinetics of onion (Allium cepa L.) slices with convective and microwave drying. Heat Mass Transf, 53, 1817-1827

Deng Y, Zhao Y, (2008). Effect of pulsed vacuum and ultrasound osmopretreatments on glass transition temperature, texture, microstructure and calcium penetration of dried apples (Fuji). LWT-Food Sci Technol, 41, 1575-1585.

Duan, X., Zhang, M., Li, X., Mujumdar, A.S. (2008). Ultrasonically enhanced osmotic pretreatment of sea cucumber prior to microwave freeze drying. Drying Technol, 26:4, 420-426.

Erbay, B., Kıvrak, E., Orhan, H., Küçüköner, E. (2009). Effect of different antioxidant solutions on the color, rehydration properties and some sensory properties of freeze dried carrot slices. SDU J Nat Appl Sci, 13:3, 229-236.

Femenia, A., Sastre-Serrano, G., Simal, S., Garau, M.C., Eim, V.S., Rossello, C. (2009). Effects of air-drying temperature on the cell walls of kiwifruit processed at different stages of ripening. LWT-Food Sci Tecbnol, 42, 106-112.

Fernandes, F.A.N., Gallao, M.I., Rodrigues, S. (2008b). Effect of osmotic dehydration and ultrasound pre-treatment on cell structure: Melon dehydration. LWT-Food Sci Technol, 41, 604-610.

Fernandes, F.A.N., Linhares, J.F.E., Rodrigues, S. (2008a). Ultrasound as pre-treatment for drying of pineapple. Ultrason Sonochem, 15:6, 1049-1054.

Fernandes, F.A.N., Oliveira, F.I.P., Rodrigues, S. (2008c). Use of ultrasound for dehydration of papayas. Food Bioproc Tech, 1, 339-345.

Fernandes, F.A.N., Rodrigues, S. (2007). Ultrasound as pre-treatment for drying of fruits: Dehydration of banana. J Food Eng, 82, 261-267. 
Fernandes, F.A.N., Rodrigues, S. (2008). Application of ultrasound and ultrasound-assisted osmotic dehydration in drying of fruits. Drying Technol, 26:12, 1509-1516.

Fernandes, F.A.N., Rodrigues, S., Law, C.L., Mujumdar, A.S. (2011). Drying of exotic tropical fruits: A comprehensive review. Food Bioproc Tech, 4:2, 163-185.

Fijalkowska, A., Nowacka, M., Wiktor, A., Sledz, M., Witrowa-Rajchert, D. (2016). Ultrasound as a pretreatment method to improve drying kinetics and sensory properties of dried apple. J Food Process Eng, 39, 256-265.

Franke, S.I.R., Chless, K., Silveria, J.D., Robensam, G. (2004) Study of antioaksidant and mutajenic activity of different orange juice. Food Chem, 88, 45-55.

Gamboa-Santos, J., Montilla, A., Cárcel, J.A., Villamiel, M., Garcia-Perez, J.V. (2014) Air-borne ultrasound application in the convective drying of strawberry. J Food Eng, 128, 132-139.

Garcia-Noguera, J., Oliveira, F.I.P., Gallão, M.I., Weller, C.L., Rodrigues, S., Fernandes, F.A.N. (2010). Ultrasound-assisted osmotic dehydration of strawberries: effect of pretreatment time and ultrasonic frequency. Drying Technol, 28, 294-303.

Gogus, F., Maskan, M. (2001). Drying of olive pomace by a combined microwave-fan assisted convection oven. Nahrung/Food, 45, 129-132.

Gorinstein, S., Haruenkit, R., Poovarodom, S., Park, Y.S., Vearasilp, S., Suhaj, M., Hamg, K.S., Heo, B.G., Cho, J.Y., Jang, H.G. (2009). The comparative characteristics of snake and kiwi fruits. Food Chem Toxicol, 47, 1884-1891.

Goula, A.M., Adamopoulos, K.G. (2005). Spray drying of tomato pulp in dehumidified air: II. The effect on powder properties. J Food Eng, 66, 3542.

Hışıl, Y. (2004) Instrumental Food Analysis and Laboratory Experiments. Ege University Engineering Faculty Books, 45, İzmir-Turkey

İçier, F., Yıldız, H., Eroğlu, S., Sabanc1, S., Eroğlu, E. (2013). Effect of electrical and ultrasonic pre- treatments during osmotic dehydration of quince slices. Academic Food J, 11:2, 60-69.

Jambrak, A.R., Mason, T.J., Paniwnyk, L., Lelas, V. (2007). Accelerated drying of button mushrooms, Brussels sprouts and cauliflower by applying power ultrasound and its rehydration properties. J Food Eng, 81(1), 88-97.

Kadi, H., Hamlat, M.S. (2002). Studies on drying kinetics of olive foot cake. Grases Aceites, 53, 226228

Kaya, A., Aydın, O., Dincer, İ. (2008). Experimental and numerical investigation of heat and mass transfer during drying of Hayward kiwi fruits (Actinidia Deliciosa Planch). J Food Eng, 88, 323-330.

Kaya, A., Aydın, O., Kolaylı, S. (2010). Effect of different drying conditions on the vitamin $\mathrm{C}$ (ascorbic acid) content of Hayward kiwi fruits (Actinidia deliciosa Planch). Food and Bioprod Process, 88, 165-173.

Kek, S.P., Chin, N.L., Yusof, Y.A. (2013). Direct and indirect power ultrasound assisted preosmotic treatments in convective drying of guava slices. Food Bioprod Process, 9, 495-506.

Lee, J.W., Feng, H., Kushad, M. (2005). Effect of Manothermosonication (MTS) on quality of orange juice. Presented at AIChE Annual Meeting, (Cincinnati).

Magalhãesa, M.L., Cartaxo, S.J.M., Gallão, M.I., García-Pérez, J.V., Cárcel, J.A., Rodrigues, S., Fernandes, F.A.N. (2017). Drying intensification combining ultrasound pre-treatment and ultrasound-assisted air drying. J Food Eng, 215, 7277.

Maskan, M. (2001). Kinetics of colour change of kiwifruits during hot air and microwave drying. $J$ Food Eng, 48(2): 169-175

Miano, A.C., Ibarz, A., Augusto, P.E.D. (2016) Mechanisms for improving mass transfer in food with ultrasound technology: Describing the phenomena in two model cases. Ultrason Sonochem, 29, 413-419

Mohammadi, A., Rafiee, S., Emam-Djomeh, Z., Keyhani, A. (2008). Kinetic models for colour 
changes in kiwifruit slices during hot air drying. World J Agric Sci, 4(3), 376-383.

Mulet, A., Cárcel, J.A., Sanjuán, N., Bon, J. (2003). New food drying technologies use of ultrasound. Food Sci Technol Int, 9, 215-221.

Nowacka, M., Wiktor, A., Sledz, M., Jurek, N., Witrowa-Rajchert, D. (2012) Drying of ultrasound pretreated apple and its selected physical properties. J Food Eng, 113, 427-433.

Opalic, M., Domitran, Z., Komes, D., Belšcak, A., Horzic', D., Karlovic', D. (2009). The effect of ultrasound pre-treatment and air-drying on the quality of dried apples. Czech J Food Sci. 27, 297300.

Park, Y.S., Namiesnik, J., Vearasilp, K., Leontowicz, H., Leontowicz, M., Barasch, D., Nemirovski, A., Trakhtenberg, S., Gorinstein, S. (2014). Bioactive compounds and the antioxidant capacity in new kiwi fruit cultivars. Food Chem, 165, 354-361.

Pingret, D., Fabiano-Tixier, A.S., Chemat, F. (2013). Degradation during application of ultrasound in food processing: A review. Food Control, 31, 593-606.

Ricce, C., Rojas, M.L., Miano, A.C., Siche, R., Augusto, P.E.D. (2016) Ultrasound pretreatment enhances the carrot drying and rehydration. Food Res Int, 89(1), 701-708.

Rojas, M.L., Leite, T.S., Cristianini, M., Alvim, I.D., Augusto, P.E.D. (2016). Peach juice processed by the ultrasound technology: Changes in its microstructure improve its physical properties and stability. Food Res Int, 82, 22-33.

Santacatalina, J.V., Cárcel, J.A., Simal, S., GarciaPerez, V., Mulet, V. (2012). Atmospheric freeze drying assisted by power ultrasound. International Symposium on Ultrasound in the Control of Industrial Processes. Mater Sci Eng, 42:012021.
Schössler, K., Jäger, H., Knorr, D. (2012). Novel contact ultrasound system for the accelerated freeze-drying of vegetables. Innov Food Sci Emerg Technol, 16, 113-120.

Simal, S., Femenia, A., Garau, M.C., Rossell, C. (2005). Use of exponential, Page's and diffusional models to simulate the drying kinetics of kiwi fruit. J Food Eng, 66, 323-328.

Stojanovic, J., Silva, J.L. (2007). Influence of osmotic concentration, continuous high frequency ultrasound and dehydration on antioxidants, colour and chemical properties of rabbiteye blueberries. Food Chem, 101(3), 898-906.

Tekgül, Y, Çalışkan Koç, G. (2020). Arapsaçi otunun (foeniculum vulgare) kuruma kinetiğinin incelenmesi ve kuruma davranişinin modellenmesi. Gida, 45(4): 676-688.

Toosi, S.B., Maghsoudlou, Y., Bolouri, B., Eshraghi, E. (2011). Modelling effect of ultrasound pretreatment on drying kinetics of kiwifruit. International Congress on Engineering and Food, Atina, Greece.

Vega-Gálvez, A., Ah-Hen, K., Chacana, M., Vergara, J., Martinez-Monzo, J., Garcia-Segovia, P., Lemus-Mondaca, R., Di Scala, K. (2012). Effect of temperature and air velocity on drying kinetics, antioxidant capacity, total phenolic content, colour, texture and microstructure of apple (var. Granny Smith) slices. Food Chem, 132, 51-59.

Wang, J., Xi., Y.S. (2005). Drying characteristics and drying quality of carrot using a two-stage microwave process. J Food Eng, 68, 505-511.

Wang, W.C., Sastry, SK. (2002). Effects of moderate electrothermal treatments on juice yield from cellular tissue. Innov Food Sci Emerg Technol, 3, 371-377. 